Jolanta Bąk-Badowska *, Ilona Żeber-Dzikowska **, Jarosław Chmielewski ***

\title{
Evaluation of the degree of healthiness of the pedunculate oak (Quercus robur L.) acorns in the Włoszczowa- Jędrzejów Nature Park and its neighbouring area
}

\section{Ocena stopnia zdrowotności żołędzi dębu szypułkowego (Quercus robur L.) we Włoszczowsko-Jędrzejowskim Obszarze Chronionego Krajobrazu i terenie przyległym}

* Dr hab. Jolanta Bąk-Badowska - Institute of Biology, The Jan Kochanowski University, Świętokrzyska 15 St., 25-406 Kielce, e-mail: jolanta.bak@ujk.edu.pl ** Dr hab. Ilona Żeber-Dzikowska, Prof. Nadzw. - Institute of Humanities in Płock, Gałczyńskiego 28 St., 09-400 Płock; Institute of Biology, The Jan Kochanowski University in Kielce, Świetokrzyska 15 St., 25-406 Kielce; e-mail: ilona.zeber-dzikowska@ujk.edu.pl
*** Dr Jarosław Chmielewski - Institute of Environmental Protection-National Research Institute, Krucza 5/11d St., 00-548 Warsaw, e-mail: jaroslaw.chmielewski@ios.edu.pl

Keywords: oak, damage to acorns, insects, the Włoszczowa-Jędrzejów Nature Park, the Świętokrzyskie Province Słowa kluczowe: dąb, uszkodzenia żołędzi, owady, Włoszczowsko-Jędrzejowski Obszar Chronionego Krajobrazu, województwo świętokrzyskie

\section{Abstract}

The aim of the study was to demonstrate the degree of healthiness of the pedunculate oak (Quercus robur) acorns found in the Włoszczowa-Jedrzejów Nature Park (abbreviation: W-JOChK) and in the neighbouring area. It was dealt with by making the analysis of health of the acorns (total 3,600). The research material included the samples of fallen down acorns, collected under the pedunculate oaks in Kurzelów (W-JOChK), as well as Żelisławice. The study was conducted from late September 2014 to early October 2015.

The analysis of acorns demonstrated that over $50 \%$ of the acorns were damaged by insects. The 'perpetrators' of the damage proved to be Curculio glandium (Coleoptera: Curculionidae acorn weevil) and Cydia splendana (Lepidoptera: Tortricidae chestnut tortrix). It was stated that acorns from the pedunculate oak trees, which were found on the protected area, were twice less frequently inhabited by Curculio glandium than those originating from the trees in Żelisławice - near the industrial firm. The damages caused by Cydia splendana in both study sites were similar in number. The results indicate that the acorns of oaks in more polluted environment are probably more vulnerable to infestation by insects.

(C) IOŚ-PIB

\section{INTRODUCTION}

The oaks of Quercus spp. are a common species occurring in our country; they are the deciduous species of the beech family (Fagaceae). In Poland, forest stands covered with this species of oak extends over the area of over 600,000 ha, that is, approximately $7.5 \%$ of the forest area [Leśnictwo 2015]. These trees are an important part of the forest stands with regards to both economic and natural terms. Pedunculate oaks (Quercus robur) and sessile oaks (Quercus petraea) are native to Poland, whereas northern red oaks (Quercus rubra), Turkey oaks (Quercus cerris), pink oaks (Quercus palustris), downy oaks

\section{Streszczenie}

Celem badań było wykazanie stopnia zdrowotności żołędzi dębów szypułkowych (Quercus robur L.) rosnących we WłoszczowskoJędrzejowskiem Obszarze Chronionego Krajobrazu (W-JOChK) i na terenie przyległym. Badany materiał stanowiły próby opadłych żołędzi (łącznie 3600), które analizowano pod kątem ich zdrowotności. Próby żołędzi zebrano pod dębami w miejscowości Kurzelów (W-JOChK) oraz w Żelisławicach pod koniec września i na początku października w latach 2014-2015.

Analiza żołędzi wykazała, że ponad 50\% żołędzi zostało uszkodzonych przez owady. Sprawcami uszkodzeń okazały się: słonik żołędziowiec (Curculio glandium Marsh.) (Coleoptera: Curculionidae) i pachówka żołędzióweczka (Cydia splendana Hb.) (Lepidoptera: Tortricidae). Stwierdzono, że żołędzie dębów rosnących na obszarze chronionym były dwukrotnie rzadziej zasiedlone przez słonika żołędziowca niż pochodzące z drzew w Żelisławicach - w pobliżu zakładu przemysłowego. Uszkodzenia wywołane przez pachówkę żołędzióweczkę na obydwu stanowiskach były ilościowo zbliżone. Otrzymane wyniki wskazują, że żołędzie dębów na terenie środowiska bardziej zanieczyszczonego prawdopodobnie są bardziej podatne na zasiedlanie przez owady.

(Quercus pubescens) and others, represent the so-called alien or non-indigenous species, namely the introduced species.

Owing to the economic and ecological reasons, the pedunculate oak tends to be an important forest of the deciduous species of Europe. Because of its great adaptive abilities to different climatic conditions, this oak can be found nearly in whole Europe, starting from the north-western Spain, up to the north-eastern European part of Russia [Kremer 1996]. Nowadays, in many European countries, including Poland, the forest economy that is consistent with nature is promoted. Moreover, its priority is related to the 
natural renewals. Subsequently, there is a strong demand for healthy acorns.

As already mentioned, in Poland, the pedunculate oak is the most common species. Nevertheless, in Europe, the dieback of oaks has been observed since the early $18^{\text {th }}$ century [Oszako 2000]. It has been because these trees are sensitive to both low temperatures and long-lasting droughts. Impaired by abiotic factors, they often suffer from fungal pathogens and pests [Balder 1990, Delatour and Morelet 1990, Przybył 1990, Siwecki 1990, Modrzyński et al. 2006, Jaworski 2011]. In our country, there had been no dieback of oaks on a larger scale until the 80's of the last century. However, this process has become evident in the recent years. Among all woody plants, the most frequent and wide-ranging fauna of arthropods occurs on oaks. One can discover more than 1,200 herbivorous species on these trees, including insects, that form galls on leaves, stems and roots, mainly from the gall wasp family (Cynipidae, Hymenoptera) and gall midges (Cecidomyiidae, Diptera) [Stone, Schönrogge 2003]. These pests decrease the decorative qualities of oaks, causing damage to buds and leaf blades, and due to their large numbers, they influence the growth of trees by suppressing the trees and by having a negative effect on their health. Other insects damage the oak fruit. The information dealing with the occurrence of insects damaging oak acorns and its consequences can be found in the publications by Čermak [1952], Schnaider [1976], Krístek, Skrzypczyńska [1992], Kelbel [1996] and Stocki et al. [2007].

The larvae of Curculio glandium (Coleoptera: Curculionidae) and the caterpillars of Cydia splendana (Lepidoptera: Tortricidae) are one of the most frequently referred to 'perpetrators' damaging the acorns [Kapuściński 1966, Skrzypczyńska 1999, Bąk 2002, Jankowiak 2008].

The analysis of species structure of forest stands in the Włoszczowa-Jędrzejów Nature Park signifies that Scots pine (Pinus sylvestris) and European alder (Alnus glutinosa) are the dominant species there. The oaks, however, constitute only $1.8 \%$ of the forest area. Owing to the previous indication of their economic and ecological importance; therefore, it was sensible and advisable to increase the number of this species in the above-mentioned area. Due to this reason, the researches were conducted with the aim to demonstrate the differences in the settlement of insects in the acorns coming from pedunculate oaks (Quercus robur) growing in Włoszczowa-Jędrzejów Nature Park, considering the place in which they occurred. The researches involved finding the 'perpetrators' (insects) responsible for damaging the acorns, and therefore, the losses in the analysed material.

\section{STUDY SITE}

The National Park, numerous nature reserves, landscape parks and nature parks located in the Świętokrzyskie Province create the system of the protected areas. This system constitutes a spatial arrangement of the mutually completing forms of the nature conservation. The Włoszczowa-Jędrzejów Nature Park is one of the 21 protected landscape areas, covering $41 \%$ of the Świętokrzyskie Province. It is situated in the western and central parts of the province, covering the area of over 69,000 ha. The research was carried out in two study sites (Fig. 1), which were situated in the National Forest Holding, namely, the Forest District of Włoszczowa.

The first study site was in village Kurzelów in the WłoszczowaJędrzejów Nature Park. The forest type, in this area, is characterised by fresh mixed coniferous forest and the tree layer is dominated by Scots pine (Pinus sylvestris) (40\%) and oak $(30 \%)$ of the moderate branching habit of the tree crown. The understory vegetation consists of, among others, alder buckthorn (Frangula alnus), common hazel (Corylus avellana), rowan (Sorbus aucuparia), mountain-ash (Fraxinus excelsior) and common bird cherry (Padus avium). The research area was located at the edge of the forest stand, and the trees at the age of about $60-80$, reached a height of $10-15$ meters.

The second study site (the neighbouring area of the village Żelisławice) was outside the Włoszczowa-Jędrzejów Nature Park, that is, near the industrial firm called Prefabet, which produces concrete. The species constituting the forest stand in this area included Scots pine $(20 \%)$, oak $(10 \%)$ and larch (Larix spp. ,10\%). The understory vegetation is dominated by birch (Betula spp.), pine tree and oaks. The trees chosen for the research were at the edge of the fresh coniferous forest. They were located along the road, which could be characterised by heavy traffic, connecting the village Żelisławice to the village Secemin. The trees were of a similar height, namely from 10 to $15 \mathrm{~m}$, considering the moderate branching habit of the tree crown. This area was close to the fields.

\section{RESEARCH MATERIAL AND METHODS}

The research material comprised of samples of fallen down acorns, collected under the oaks in the study site in Kurzelów (the Włoszczowa-Jędrzejów Nature Park) and the village of Żelisławice (outside the protected area). The research was conducted in late September and early October, in the period of 2014 to 2015 . In 2014, 8 trees from each study site were considered, while in 2015, 10 trees from each study site were studied. The location of trees allowed to correspond the samples of acorns to the individual trees, namely, 100 acorns were randomly collected under every oak tree.

The collected material was placed in the laboratory, and then, it was analysed. The number of acorns that were healthy, wasted (i.e., incapable of germination) or damaged by insects was determined. During the analysis of the damages, the scientific description of Kapuściński [1966] was used.

The research description used the statistical analysis of variance (two-way, or two-factor analysis). The surface and the year of research were considered as the classifying factors. Before data analysis, the following assumptions were examined [StatSoft 2004]:

variability of a sample and the empirical distributions (if they came from the normal distribution), which was evaluated using the Shapiro-Wilk test [Sokal, Rohlf 2012]

the equality of variances for the two compared groups using Levene's test [Sokal and Rohlf 2012]. 


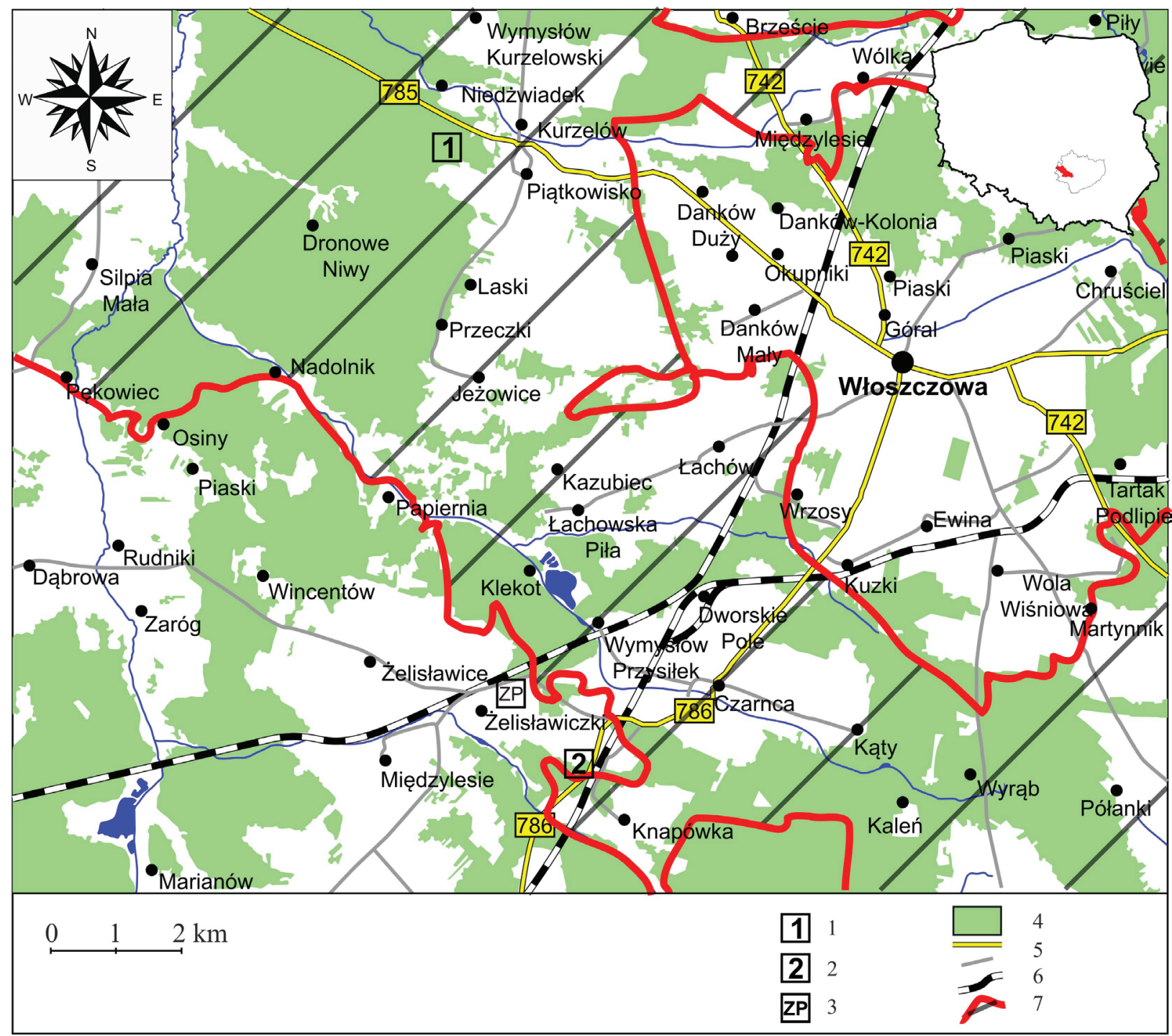

Figure 1. Research area: 1 - study site in Kurzelów, 2 - study site in Żelisławice, 3 - industrial firm called Prefabet, 4 - forest areas, 5 - roads, 6 - railway line, 7 - areas of the Włoszczowa-Jędrzejów Nature Park.

\section{RESULTS OF THE RESEARCH AND THE DISCUSSION}

The examination of 3600 pedunculate acorns indicated that 488 acorns (i.e., 13.5\%) were capable of germination, 1,219 (i.e., $33.9 \%$ ) were wasted acorns and the remaining 1,893 acorns (i.e., $52.58 \%$ ) were found damaged. These damaged acorns included 1,233 acorns (i.e., 34.3\%) damaged by Cydia splendana and 660 acorns (i.e., 18.3\%) damaged by Curculio glandium (Coleoptera: Curculionidae) (Table 1).

Analysing the data for the examined acorns in the study site in Kurzelów in both years put together (Fig. 2), the above mentioned insects damaged 876 acorns (i.e., $48.6 \%$ ), including $37.4 \%$ by Cydia splendana and $11.2 \%$ by Curculio glandium, from the total 1,800 collected acorns. The healthy acorns were only 145 (i.e., $8.1 \%)$, and the wasted acorns were 779 (43.3\%).

In 2015, in the study site in Kurzelów, the percentage of acorns wasted and damaged by Cydia splendana was higher than the previous year, respectively $49.1 \%$ (in 2015) and 36\% (in 2014)
- wasted acorns and 42.8\% (in 2015) and 30.8\% (in 2014) damaged (Fig. 3)

However, in the study site in Żelisławice, $56.5 \%$ of acorns were damaged. There were $343(19.1 \%)$ healthy acorns and 440 $(24.4 \%)$ wasted acorns (Fig. 4). Also, in this study site, a greater number of acorns - wasted and damaged by Cydia splendana was recorded in 2015 than in 2014 (Fig. 5).

During the two-year research, it was verified that acorns from oaks situated near the industrial firm called Prefabet in Żelisławice were twice more frequently colonised by Curculio glandium (25.4\%) than acorns from oak trees found in the protected areas (11.2\%). However, the damages caused by Cydia splendana in both study sites were similar $-37.4 \%$ and $31.1 \%$ (Fig. 2, 4) respectively.

The analysis of variances showed the influence of surface and year of research on the percentage of damage to pedunculate acorns by Curculio glandium and Cydia splendana.

In the case of first insect, the factor was $F_{1.32}=45,3658$ and $p \leq$ 0.001 for the study site, whereas $F_{1.32}=76,6109$ and $p \leq 0.001$ was determined for the year. However, for Cydia splendana, 
Table 1. Results of analysis of pedunculate acorns collected in both Kurzelów and Żelisławice during 2014-2015.

\begin{tabular}{|c|c|c|c|c|c|c|c|c|}
\hline \multirow{4}{*}{$\begin{array}{c}\text { Number of } \\
\text { pedunculate } \\
\text { acorns }\end{array}$} & \multicolumn{8}{|c|}{ Number and percentage of pedunculate acorns } \\
\hline & \multirow{2}{*}{\multicolumn{2}{|c|}{ healthy }} & \multirow{2}{*}{\multicolumn{2}{|c|}{ wasted }} & \multicolumn{4}{|c|}{ damaged by } \\
\hline & & & & & \multicolumn{2}{|c|}{ C. splendana } & \multicolumn{2}{|c|}{ C. glandium } \\
\hline & No. & $\%$ & No. & $\%$ & No. & $\%$ & No. & $\%$ \\
\hline 3,600 & 488 & 13.5 & 1,219 & 33.9 & 1,233 & 34.3 & 660 & 18.3 \\
\hline
\end{tabular}

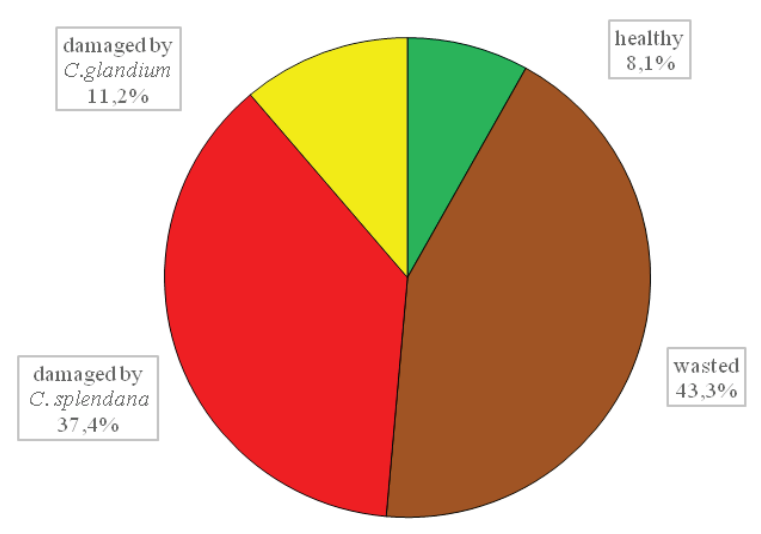

Figure 2. The quality of pedunculate acorns collected from the study site in Kurzelów, in the period of 2014-2015.

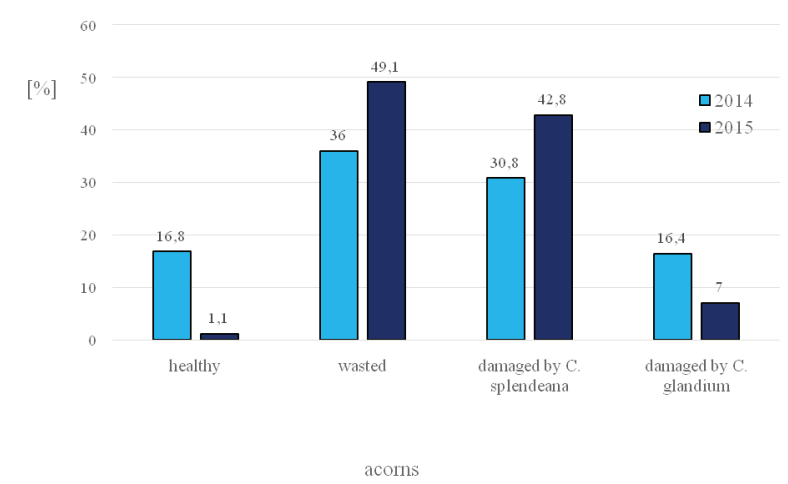

Figure 3. The analysis of pedunculate acorns collected from the study site in Kurzelów, in subsequent years of the research.

it was $F_{1,32}=46,013 ; p \leq 0.001$ (for first study site) and $F_{1.32}=$ 77,$550 ; p \leq 0.001$ (for the year).

In our country, the great need for healthy acorns has occurred because of the gradual deterioration in the healthiness of oaks. Considering the data for pedunculate acorn collected in the years 1951-1999, it appears that, in Poland, a rich harvest of acorns can be observed every 5-7 years on average [Kantorowicz 2000]. As per other authors, the pedunculate oak has a rich harvest of acorns every 3-8 years [Suszka et al. 1994]. The trees found in the same tree stand can produce acorns, which vary in both size and shape. Consequently, owing to the requirement of protecting and preserving the genetic diversity, both large and heavy, as

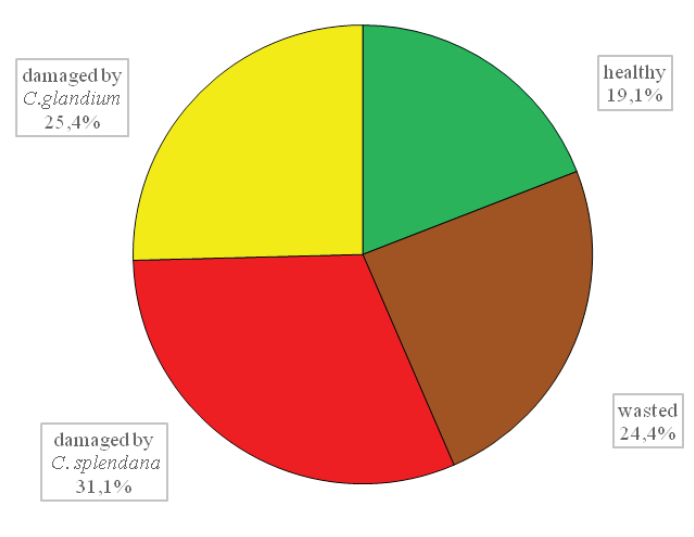

Figure 4. The quality of pedunculate acorns collected from the study site in Żelisławice, in the period of 2014-2015.

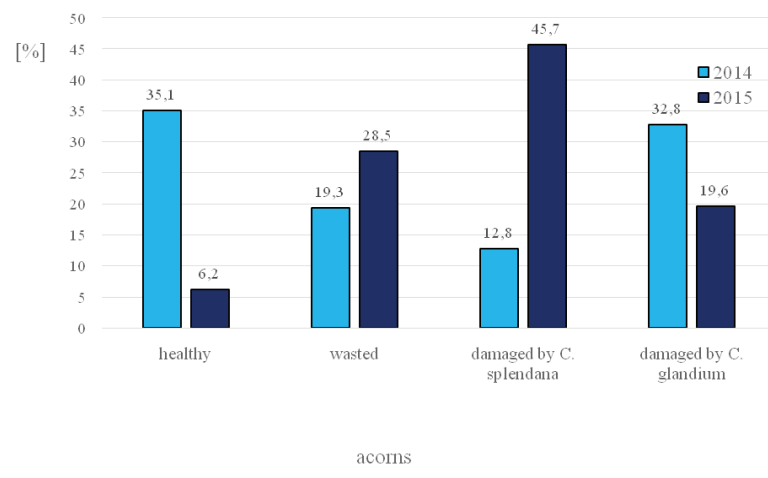

Figure 5. The analysis of pedunculate acorns collected from the study site in Żelisławice, in the subsequent years of the research.

well as small and light acorns must be collected and stored [Falleri and Pacella 1997]. According to Tyszkiewicz [1952], the healthiness of pedunculate acorns ranges from $60 \%$ to $70 \%$, and as far as other species are concerned, for example, the northern red oak, their healthiness reaches even up to $90 \%$.

The main cause of oak dieback can possibly be the influence of the co-occurrence of many abiotic and biotic factors. One of the biotic factors causing the damage of acorns is related to insects, among which, the most common are mentioned above, namely, Curculio glandium and Cydia splendana.

As per the research carried out in the Włoszczowa-Jędrzejów Nature Park, it was stated that the aforementioned insects 
damaged the pedunculate acorns to a significant extent. Bearing in mind the 3,600 examined acorns, these species destroyed more than $50 \%$ of them.

One of the research sites is located in the protected area; therefore, it is worth comparing the results from this site with other protected areas. The research conducted by Skrzypczyńska [1999] in the Ojców National Park (OPN), which involved the acorns from the red oak and pedunculate oak, showed the damage caused by both Curculio glandium and Cydia splendana. Considering the three study sites, the above-mentioned insects damaged $39.5 \%$ acorns in total $(29.5 \%$ by Curculio glandium and $10 \%$ by Cydia splendana). These results apply only to the damage in the range of pedunculate acorns. In the case of northern red oak, the damage was much smaller $-4.5 \%$ by Curculio glandium and $0.5 \%$ by Cydia splendana. The number of healthy pedunculate acorns in the Ojców National Park was more than three times greater than the current examination. On the other hand, Bąk [2002] claims that the two-year research conducted in three study sites located in Kielce and Cisów-Orłowiny Landscape Park in the Świętokrzyskie Province, concerning the acorns from pedunculate, sessile and northern red oaks, showed that the pedunculate acorns were the most vulnerable to the colonisation of insects (mainly Curculio glandium and Cydia splendana). It is worth mentioning that these trees were situated along a busy road in Kielce. Curculio glandium damaged $22.6 \%$ of 4,800 of acorns and Cydia splendana damaged $8.25 \%$. The outcome confirming the vulnerability of acorns from the sessile oak to the insect colonisation (mainly Curculio glandium) were acknowledged by Skrzypczyńska [1999], whose research was carried out in the Ojców National Park in the study sites at Kraków Gate, Golden Mount', near Skała and Jerzmanowice. Furthermore, Szujecki [1998] also recognises great damages caused by Curculio glandium in the oak forests of Ukraine and southern Europe. According to the research conducted in Slovakia by Kelbel [1996], the loss of acorns from sessile oaks caused by the aforesaid insects were less significant there, and they reached approximately $20 \%$.

\section{REFERENCES}

BALDER H. 1990. The role of Ceratocystis species in oak decline. In: Siwecki R, Liese, W. (ed.). Oak decline in Europe. Proceedings of an International Symposium. Kórnik, Poland, PWRiL, Poznań: 75-81.

BĄK J. 2002. Owady uszkadzające żołędzie dębów (Quercus spp.) na terenie Kielc i Cisowsko-Orłowińskiego Parku Krajobrazowego. Rocznik Świętokrzyski 28: 1-5.

ČERMAK K. 1952. Hmyzi škudci semen našich lesnich dřevin. Práce výskumních ústavů lesnických. I. Ochrana lesa 5:5-87.

DELATOUR C., MORELET M. 1990. Current research on an oak decline in France, especially on Ophiostomatales. In: Siwecki R, Liese W. (ed.). Oak decline in Europe. Proceedings of an International Symposium. Kórnik, Poland, PWRiL, Poznań: 89-92.
In the current research, the attention should be drawn to the fact that acorns from sessile oaks found in Żelisławice were two time more frequently colonised by Curculio glandium than those found in Kurzelów. The oaks in Żelisławice were found in the area located near the industrial firm and in neighbouring fields. The factors diminishing the healthiness of oaks and therefore, also lowering their ability to produce acorns involve the increased content of nitrogen in water and soil. The overabundance of nitrogen supplied by water flowing from the fertilised fields [Keddy 2010] and the huge amount of nitrogen found in the tissues of oaks increase the attractiveness of oak as available food for pests. However, the so-called gaseous air pollution causes disorders in the growth of trees, changes the species composition of forests and increases the vulnerability to biotic factors, for example, the gradations of insects [Paoletti et al. 2010, Liu et al. 2011].

\section{CONCLUSIONS}

Based on the received outcomes, it can be claimed that:

1. The sessile oak acorns originating from WłoszczowaJędrzejów Nature Park and in the neighbouring area were damaged only by Curculio glandium and Cydia splendana. The mentioned insects were responsible for more than $50 \%$ of acorn losses.

2. It was indicated statistically that both study sites and the year of investigations had an impact on the number of acorns damaged by the mentioned insects.

3. The acorns from oak trees found in the protected area were twice less frequently colonised by Curculio glandium - acorn weevil, than those from oak trees located in the study site in Żelisławice (near the industrial firm). The damages caused by Cydia splendanain in both study sites were similar.

4. It is possible that the areas that were closer to industrial firms emitting pollutants, and those near the busy road, probably give preferences to more frequent occurrence of insects damaging the sessile oak acorns.

FALLERI E., PACELLA R. 1997. Applying the IDS method to remove empty seeds in Platanus acerifolia. Canadian Journal of Forest Research 27: 1311-1315.

JANKOWIAK R. 2008. Fungi occurring in acorn Quercus robur L. infested by insects. Acta Scientiarum Polonorum Silvarum Colendarum Ratio et Industria Lignaria 7, 1: 19-29.

JAWORSKI A. 2011. Hodowla lasu. Charakterystyka hodowlana drzew leśnych. T. III. PWRiL, Warszawa.

KANTOROWICZ W. 2000. Half century of seed years in major tree species in Poland. Silvae Genetica 49, 6: 245-249.

KAPUŚCIŃSKI S. 1996. Szkodniki owadzie nasion drzew leśnych. PWRiL, Warszawa.

KEDDY P.A. 2010. Wetland ecology. Principles and conservation. Cambridge University Press, Cambridge. 
KELBEL P.1996. Damage to acorns by insects in Slovakia. Biologia, Bratislava 51: 575-582.

KREMER B. T. 1996. Drzewa. Leksykon przyrodniczy. GeoCenter, Warszawa.

KŘISTEK J., SKRZYPCZYŃSKA M. 1992. Živočišni škůdci semen, šišek a plodů lesnich dřevin. W: Křistek J. (ed.). Škůdci semen, šišek a plodů lesnich dřevin. Brazda, Praha.

LEŚNICTWO 2015. Dane statystyczne GUS. Zakład Wydawnictw Statystycznych, Warszawa.

LIU X., DUAN L., MO J., DU E., SHEN S., LU X., ZHANG Y., ZHOU X., HE Ch., ZHANG F. 2011. Nitrogen deposition and its ecological impact in China: An overview. Environmental Pollution 159: 2251-2264.

MODRZYŃSKI J., ROBAKOWSKI P., ZIENTARSKI J. 2006. Zarys ekologii. W: Bugała W. (red.). Dęby. Bogucki Wydawnictwo Naukowe, Poznań - Kórnik: 411-474.

OSZAKO T. 2000. Oak declines in Europe's forests - history, causes and hypothesis. W: Oszako T., Delatour C. (ed.). Recent advances on oak health in Europe. IBL, Warszawa: 11-41.

PAOLETTI E., SCHAUB M., MATYSSEK R., WIESER G., AUGUSTIATIS A., BASTRUP-BIRK A. M., BYTNEROWICZ A., GUNTHARDT-GOERG M. S., MULLER-STARCK G., SERENGIL Y. 2010. Advances of air pollution science: From forest decline to multiple-stress effects on forest ecosystem services. Environmental Pollution 158:1986-1989.

PRZYBYŁ K. 1990. Mycoflora of the overground portions of dying Quercus robur L. W:Siwecki R, Liese W. (ed.). Oak decline in Europe. Proceedings of an International Symposium. Kórnik, Poland, PWRiL, Poznań: 141-147.
SCHNAIDER Z. 1976. Atlas uszkodzeń drzew i krzewów powodowanych przez owady i pajęczaki. PWN, Warszawa.

SIWECKI R. 1990. A decline of oak forests and attempts at biological research on this syndrome. W: Siwecki R, Liese W. (ed.). Oak decline in Europe. Proceedings of an International Symposium. Kórnik, Poland, PWRiL, Poznań: 263-270.

SKRZYPCZYŃSKA M. 1999. Uszkodzenia żołędzi dębów (Quercus spp.) w Ojcowskim Parku Narodowym. Sylwan 6: 57-59.

SOKAL R. R., ROHLF F. J. 2012. Biometry: the principles and practice of statistics in biological research. Freeman W. H. and Co. New York.

STATSOFT INC. 2010. Statistica for windows. StatSoft Inc Tulsa, Oklahoma.

STOCKI J., KINELSKI S., DZWONKOWSKI R. 2007. Szkodniki nasion i owoców drzew i krzewów leśnych. Oficyna Wydawnicza Multico, Warszawa.

STONE G.N., SCHÖNROGGE K. 2003. The adaptive significance of insect gall morphology. Trends in Ecology \& Evolution 18, 10: 512-522.

SUSZKA B., MULLER C., BONNET-MASIMBERT M. 1994 Nasiona leśnych drzew liściastych. PWN, Warszawa.

SZUJECKI A. 1998. Entomologia leśna. T. II. SGGW, Warszawa.

TYSZKIEWICZ S. 1952. Nasiennictwo leśne z zarysem selekcji drzew. PWRiL, Warszawa 